\title{
O Peculato Doloso no Direito Brasileiro
}

\author{
JORGE Guedes \\ (Promotor na Justiça do Distrito Federal)
}

1. A palavra peculato é proveniente do têrmo latino peculatus, cuja origem, por sua vez, vem de pecus - (gado) - que constituia a primitiva moeda para realização de compras e pagamento de multas. Com SERvio Tullio, em Rcma, foi introduzida a moeda cunhada. Daí, então, pela Lex Julia, peculatus, o crime, que antes era furto de gado (no seu significado primário de única riqueza monetária), passou a ser furto de cousas sagradas e desvio pelo funcionário público de dinheiros privados a êle confiados, em razão do cargo.

2. Na Direito Positivo Brasileiro - ou seja - pelo art. 312 e seu $\S 10^{\circ}$ do Código Penal, assim se conceitua o delito: "Apropriar-se o funcionário de dinheiro, valor ou qualquer outro bem móvel, público ou particular, de que tem a posse em razão do cargo, ou desviá-lo, em proveito próprio ou alheio. Pena-reclusão, de dois a doze anos, e multa, de $\operatorname{Cr} \$ 5.000,00$ a $\operatorname{Cr} \$$ $50.000,00$.

$\S 10^{\circ}$ Aplica-se a mesma pena se c funcionário público, embora não tendo a posse do dinheiro, valor ou bem, o subtrai, ou concorre para que seja subtraído, em proveito próprio ou alheio, valendo-se da facilidade que the proporciona a qualidade de funcicnário".

Façamos, a seguir, uma análise da figura delituosa.

3. Sujeito ativo do crime: E' o funcionário público, que para efeitos penais, exerce cargo, emprêgo ou função pública, mesmı transitòriamente ou sem remuneração (art. 327 do Código Penal), equiparando-se a êle quem exerce cargo, emprêgo ou função em entidade paraestatal ( $\S$ único do citado artigo).

Destarte, se o funcionário de uma autarquia, verbi gratia, do Instituto dos Comerciários, dolosamente pratica a malversaçãc do dinheiro do órgão em que trabalha, estará, sem dúvida, praticando peculato. O mesmo, porém, já não acontecerá com o funcionário do Banco do Brasil, pois êsse Banco é uma scciedade de economia mista, não se equiparando, de forma alguma, a entidade paraestatal.

Se o empregado de uma emprêsa particular, incorporada ao patrimônio nacional e transformada, a seguir, em autarquia, pratica desvio de bens dessa emprêsa após a incorporação, é êle considerado ccrmo peculatário. Essa tem 
sido, por enquanto, a corrente de pensamento majoritária. E' ela, contudo dominante por pequena diferença, porque existe outra, muito ponderável aliás, que julga sòmente aos nomeados em data posterior à incorporação poder-se atribuir a qualidade de funcionário público, por equiparacão. Assim sendo, se alguém, nessas condições, desviar bens da emprêsa encampada, estará cometendo "peculato", ao passo que se o fizer um empregado antigo, admitido antes da encampação, estará cometendo "apropriação indébita", crime muito menos grave, por ccnseguinte, no tocante à graduação da pena. A respeito, nossa opinião particular é a seguinte: Precisa-se ver, antes de qualquer julgamento a priori, a lei in concreto que concedeu a encampação. Se ela não fôr expressa no que tange o assunto, fazendo distinções, o crimincso será considerado como funcionário público e, em conseqüência, peculatório. E' aplicação da regra ubi lex non distinguit, nec nos distinguere debemus. Exemplo: A lei que determinou a encampação da Leopoldina Railway considera empregado particular, regido pela Consolidação das Leis Trabalhistas, o que era lotado, ali, antes da encampação, e funcionário público, o nomeado após.

Ficam sujeitos, ainda, às penas do peculato o co-autor que não seja funcionário público; aquêle que, nomeado para 0 cargo, não tomou posse, mas praticou atos atinentes à função, com anuência da administração; e aquêle que, nomeado irregularmente exerce o cargo enquanto a nomeação não é anulada.

4. Elementos objetivos do crime: Podem ser dinheiro, valor ou qualquer outro bem móvel, público ou particular. O dinheiro será moeda metálica ou papel-moeda, nacional ou estrangeiro, destinado ao Estado, de propriedade dêste ou não, O valor é ccnstituído pelos títulos da dívida pública, quer nacional (federal, estadual ou municipal), quer estrangeira. Bem móvel público ou particular é aquela cousa móvel capaz de proporcionar utilidade ou bem-estar, suscetivel de movimento próprio ou de remoção por fôrça alheia. Existem ccrusas móveis que a lei civil equipara às imóveis. Em Direito Penal, todavia, não há essa distinção. Por isso o navio, que, para efeito hipotecário, é considerado imóvel, em Direito Criminal é móvel, sendo, conseguintemente objeto de peculato. A eletricidade, pelo art. $155 \S 3 .^{\circ}$ do Código Penal, é equiparada à cousa móvel. Pode ser, portanto, incluída como objeto do crime de que ora se cogita. Não incidem no peculato os serviçcs. Assim, quem converter em proveito pessoal a mão-de-obra do Estado, não estará cometendo tal crime (Exemplo: Se o Diretcr de uma repartição querendo construir casa para si, afasta pedreiros lotados no órgão público que dirige e os utiliza pro domo sua).

5. Modus faciendi do peculato: O agente pode praticá-lo:

a) Aproprianda-se do bem móvel de que tem a posse em razão do cargo;

b) desviando-o, em razão do cargo, em proveito próprio ou alheio; e

c) concorrendo para que o bem, que não está na sua posse, seja subtraído, em proveito próprio ou alheio, valendo-se da facilidade que the proporciona a qualidade de funcionário. Dizem os mestres da ciência penal que, 
no caso da alínea a se dá verdadeira apropriação indébita ratione officii. No da alínea $b$, se dá destino ou uso ilícito, mas também ratione officii, a ccusas por que deve responder em quantidade e em espécie. E no da alínea c se dá contemplatione officio: o agente, valendo-se da regalia que the proporciona a qualidade de funcionário, facilita a subtração da ccusa ou concorre para que ela seja subtraída.

6. Elemento subjetivo do crime: é o dolo, ou seja o cometimento do delito pelo funcionário com a consciência da injuricidade do atc, que praticou (conscientia sceleris), e da facilidade que the proporcionou a sua qualidade funcional. Difere do peculato culposo, onde o funcionário concorre para o crime por sua imprudência, negligência ou imperícia, crime êsse praticado, lógica e òbviamente, por um terceiro, que não é seu comparsa.

7. Pena: Sendo ela de reclusão, não admite, ex vi legis, a suspensão condicicnal da pena. A lei foi sábia em punir tão rigorosamente o peculato, já que, praticado contra o bem público, assume caráter de maior gravidade. E o rigor é tal que êsse delito, tendo o máximo da pena superior a dez $a n o s$ dá azo a prisão preventiva. E mais: dá margem também a prisão administrativa, que tem a duração máxima de noventa dias. O funcionáric condenado sofre igualmente, como pena acessória (penal), a perda da função pública e a interdição de direito, constituída pela incapacidade, de cinco a vinte anos, para investidura em função pública, essa última quando a condenação fôr por tempo não inferior a quatro anos.

8. Circunstâncias excludentes e atenuantes: O pequeno valor do peculato não exime o agente, nem lhe dá qualquer benemerência especial. Já o estado de necessidade (in casu dificílimo de acontecer), devidamente comprovado, é excludente da responsabilidade criminal. O ressarcimento, porém, é simples atenuante. A reparaçãc do dano só extingue a punibilidade no peculato culposo (art. $312, \S 3 .^{\circ}$ do Código Penal), mas, nunca, no doloso. Logo, de nada vale a fiança ou caução prestada anteriormente pelo funcionário, mesmo que cubra ou ultrapasse o alcance.

9. Momento consumativo: O peculato admite tentativa onde o agente não consuma o crime por circunstâncias alheias à sua vontade. A consumação dá-se quando o funcionário remove dolosamente a cousa de que tem a posse, a desvia ou maliciosamente concorre para tanto, inccirporando-a definitivamente ao seu patrimônio ou de outrem. Para certeza da consumação não é imprescindível a prévia prestação de contas, nem a indispensável a exata fixação da quantia fraudulentamente apropriada ou desviada, desde que existam outras provas sôbre essa apropriação ou desvio. A jurisprudência tem entendido que a prestação de contas só é necessária quando o valor do prejuízo não esteja evidente, nem possa, no processo criminal, ser materialmente comprovado. Essa questão, pcrém, deve ser observada cưm grano salis com precaução e o Promotor ou o Juiz nela devem ser casuístas, ao menos por medida de economia processual: a apuração das contas é feita, a maioria das vêzes, e imediatamente, pela autoridade administrativa, de modo que a Justiça Criminal não se deve antecipar, em muitos casos, àquela autoridade administrativa enquanto não houver apuração do "deficit" ou do alcance. 
O peculato pode ainda ser instantâneo, constante de um crime único, ou ser cometido em etapas, constituindo-se em crime continuado, reconhecível conforme as condições de lugar, tempo, maneira de execução, em suma, pela sua homogeneidade objetiva.

10. Finalmente, existe, ainda, outra forma típica de peculato que é o praticado mediante êrro de outrem. Difere das formas já citadas (art. 312 e $\S 11^{\circ}$ do Código Penal), por ser executado no exercício do carǵo e não sòmente em razão do cargo. Está, essa última modalidade de peculato doloso, prevista no art. 313 do Código Penal, e de maneira tão lapidar que, para sua explicação técnica, basta a simples citação do texto legal, sem maiores comentários:

Art. 313. "Apropriar-se de dinheirc ou qualquer utilidade que, no exercício do cargo, recebeu por êrro de outrem. Pena: reclusão de um a quatro anos e multa de $\mathrm{Cr} \$ 1.000,00$ a $10.000,00 "$ ".

A máxima "governar é prever" dá uma idéia da importância que se atribui à previsão no mundo dos negócios. E' exata a afirmação de que se a previsão não constitui todo o govêrno, constitui, pelo menos, uma parte essencial do mesmo. Prever significa ao mesmo tempo, calcular o futuro e preparar-se para êle; prever é agir.

Administracion Industrial $Y$ General - HENRY FAYOL. 